\title{
MODEL PEMBELAJARAN PENANAMAN NILAI-NILAI PANCASILA PADA PELAJARAN KEWARGANEGARAAN MELALUI PENDEKATAN CONTECTUAL TEACHING AND LEARNING
}

\author{
Irwan Satria \\ Dosen IAIN Bengkulu \\ Email: satriairwan1974@gmail.com
}

\begin{abstract}
Contextual learning, enabling the learner to be active, evolves according to its potential. In the learning process, the main thing is to link all these aspects. To relate it can be done in various ways, such as material that is studied directly related to the factual conditions associated with real life experience. CTL approach is the relationship of matter or topic with real life. So in the contextual learning is how to have the learning experience owned by students always associated with actual problems that occur in the environment. Thus learning in civic education based on Pancasila values through contextual learning emphasizes the introduction, love and application of Pancasila values to learners. Learners are led to adaptation to the values of Pancasila so that it becomes a prophetic man, a human that is useful both for life itself and society, nation and state.
\end{abstract}

Keywords: Learning, Pancasila, approach

Abstrak: Pembelajaran kontekstual, memungkinkan peserta didik aktif, berkembang sesuai dengan potensinya. Didalam proses pembelajaran, yang utama adalah perlu mengaitkan seluruh aspek tersebut. Untuk mengaitkannya bisa dilakukan dengan berbagai cara, misalnya materi yang dipelajari secara langsung terkait dengan kondisi faktual yang terkait dengan pengalaman hidup yang nyata. Pendekatan CTL adalah keterkaitan materi atau topik dengan kehidupan nyata. Jadi di dalam pembelajaran kontekstual adalah bagaimana agar pengalaman belajar yang dimiliki siswa senantiasa terkait dengan permasalahan-permasalahan aktual yang terjadi di lingkungannya. Dengan demikian pembelajaran dalam pendidikan kewargaanegara berdasarkan nilai-nilai pancasila melalui pembelajaran kontekstual menekankan pada pengenalan, mencintai dan penerapan nilai-nilai pancasila terhadap peserta didik. Peserta didik digiring pada adaptasi terhadap nilai-nilai pancasila sehingga menjadi manusia profetik, manusia yang berguna baik untuk kehidupan diri sendiri maupun masyarakat, bangsa dan negara.

Kata Kunci: Pembelajaran, Pancasila, pendekatan

\section{Pendahuluan}

Pendidikan kewarganegaraan merupakan mata pelajaran yang berbeda dengan mata pelajaran lain yang lebih menonjolkan kemampuan kognitif dan afektif peserta didik. Oleh karena itu agar pembentukan dan pengembangan karakter berdasarkan nilai kebangsaan peserta didik efektif dan efisien, diperlukan pemilihan metode dan materi yang sesuai.

Meskipun demikian apapun metode yang dipilih, hal yang harus digaris bawahi adalah perlunya pelibatan seluruh aspek dan perilaku peserta didik secara simultan. Dalam hal ini pembelajaran yang cenderung doktriner dan hanya menghidupkan as- pek kognitif peserta didik harus dihindari. Metode yang dibutuhkan adalah metode yang menghidupkan ketiga aspek yakninya kognitif, affektif dan psikomotor serta membawa peserta didik ke dalam pengalaman nyata kehidupan berdasarkan nilainilai pancasila.

Kesesuaian metode dan materi yang berbasis nilai-nilai pancasila dalam pembelajaran menghasilkan perubahan perilaku. Pemerintah telah mengeluarkan Permendiknas 23/2006 tentang standar keberhasilan pendidikan yang juga sebagai standar hasil pendidikan karakter. Standar secara umum ini berhubungan dengan perilaku sesuai karakter yang diinginkan yaitu : Berperilaku sesuai 
dengan ajaran agama yang dianut sesuai dengan perkembangan remaja, Mengembangkan diri secara optimal dengan memanfaatkan kelebihan diri serta memperbaiki kekurangannya, Menunjukkan sikap percaya diri dan bertanggung jawab atas perilaku, perbuatan, dan pekerjaannya, Berpartisipasi dalam penegakan aturan-aturan sosial, Menghargai keberagaman agama, bangsa, suku, ras, dan golongan sosial ekonomi dalam lingkup global, Membangun dan menerapkan informasi dan pengetahuan secara logis, kritis, kreatif, dan inovatif, Menunjukkan kemampuan berpikir logis, kritis, kreatif, dan inovatif dalam pengambilan keputusan, Menunjukkan kemampuan mengembangkan budaya belajar untuk pemberdayaan diri, Menunjukkan sikap kompetitif \& sportif untuk mendapatkan hasil yang terbaik, Menunjukkan kemampuan menganalisis dan memecahkan masalah kompleks, Menunjukkan kemampuan menganalisis gejala alam dan sosial, Berperilaku sesuai dengan ajaran agama yang dianut sesuai dengan perkembangan remaja, Mengembangkan diri secara optimal dengan memanfaatkan kelebihan diri serta memperbaiki kekurangannya, Menunjukkan sikap percaya diri dan bertanggung jawab atas perilaku, perbuatan, dan pekerjaannya, Berpartisipasi dalam penegakan aturan-aturan sosial, Menghargai keberagaman agama, bangsa, suku, ras, dan golongan sosial ekonomi dalam lingkup global, Membangun dan menerapkan informasi dan pengetahuan secara logis, kritis, kreatif, dan inovatif, Menunjukkan kemampuan berpikir logis, kritis, kreatif, dan inovatif dalam pengambilan keputusan, Menunjukkan kemampuan mengembangkan budaya belajar untuk pemberdayaan diri, Menunjukkan sikap kompetitif \& sportif untuk mendapatkan hasil yang terbaik, Menunjukkan kemampuan menganalisis dan memecahkan masalah kompleks dan menunjukkan kemampuan menganalisis gejala alam dan sosial.

Berdasarkan penjelasan di atas maka perlu penanaman nilai-nilai pancasila dalam pembelajaran pendidikan kewarganegaraan melalui pendekatan CTL.

\section{Pembahasan}

Carter V. Good dalam Jalaluddin dan Abdullah (1999:40) menyatakan bahwa pendidikan merupakan proses perkembangan kecakapan seseorang dalam bentuk sikap dan tingkah laku seseorang. Menurut Mansyur Ramly (2010:9), pendidikan merupakan upaya terencana dalam mengembangkan potensi peserta didik, sehingga mereka memi- liki sistem berpikir, nilai, moral, dan keyakinan yang diwariskan masyarakatnya dan mengembangkan warisan tersebut ke arah yang sesuai untuk kehidupan masa kini dan masa mendatang. Sedangkan menurut Qomari Anwar (2010), pendidikan adalah proses internalisasi nilai-nilai budaya ke dalam diri seseorang dan masyarakat sehingga membuat orang dan masyarakat jadi beradab. Pendidikan bukan merupakan sarana transfer ilmu pengetahuan saja, tetapi lebih luas lagi yakni sebagai sarana pembudayaan dan penyaluran nilai (enkulturisasi dan sosialisasi).

Dari penjelasan di atas maka pendidikan pada dasarnya merupakan aktivitas atau proses sosial budaya masyarakat. Pada perspektif ini pendidikan adalah proses transmisi kebudayaan. Menurut Manan (1989:9), pendidikan mencakup setiap proses, kecuali yang bersifat genetis, yang menolong membentuk fikiran, karakter atau kapasitas fisik seseorang. Proses tersebut berlangsung seumur hidup. Sejumlah nilai-nilai budaya ditransmisikan kepada peserta didik. Menurut Mansyur Ramly (2010: 3-4), pendidikan adalah suatu usaha yang sadar dan sistematis dalam mengembangkan potensi peserta didik. Pendidikan adalah suatu usaha masyarakat dan bangsa dalam mempersiapkan generasi mudanya bagi keberlangsungan kehidupan masyarakat dan bangsa yang lebih baik di masa depan. Keberlangsungan itu ditandai oleh pewarisan nilai budaya dan karakter yang telah dimiliki masyarakat dan bangsa. Esensi pendidikan menurut Daud Joesoef (Kompas, 3 Sept 2008), adalah proses yang membiasakan manusia sedini mungkin untuk mempelajari, memahami, menguasai dan menerapkan nilai-nilai yang disepakati bersama sehingga berguna bagi individu, masyarakat, bangsa dan negara.

Dengan demikian dari perspektif budaya hakekat pendidikan merupakan pewarisan nilainilai budaya berupa sejumlah pengetahuan, keterampilan, nilai-nilai moral. Nilai-nilai tersebut merupakan nilai-nilai kehidupan yang berguna bagi peserta didik dalam kehidupannya baik untuk diri sendiri maupun didalam kehidupan bermasyarakat. Nilai-nilai itu mengisi atau mewarnai dari karakter seseorang, seperti nilai taqwa, cerdas, bertanggungjawab, menghargai kemanusiaan, kebangsaan (nasionalis), mandiri, jujur, kerjasama dan demokratis yang tercermin pada tingkah laku kehidupan sehaihari.

Dalam konsep pendidikan tidak lepas dari beberapa pandangan aliran. Aliran Essensialisnme berpandangan bahwa pendidikan harus bersendi- 
Irwan S atria| Model Pembelajaran Penanaman Nilai-Nilai Pancasila 155

kan nilai-nilai yang dapat mendatangkan manfaat dan kestabilan dalam masyarakat. Dalam aliran ini yang paling utama dalam pendidikan adalah pewarisan nilai-nilai yang bermanfaat dalam kehidupan umat manusia. Menurut Suwarno (2006:5556), belajar merupakan proses pewarisan nilai-nilai budaya ke generasi berikutnya. Nilai-nilai tersebut menjadi penuntun dalam bersikap dan berperilaku anggota masyarakat. Nilai-nilai menjadi tatanan dan pedoman hidup, sehingga dapat mencapai kebahagian. Nilai-nilai berasal dari filsafat dan kebudayaan suatu masyarakat. Oleh karena itu dalam pandangan ini pendidikan merupakan aktivitas belajar dalam rangka pewarisan nilai-nilai sosal budaya.

Nilai-nilai yang diwarisi dalam pembelajaran akan mendasari setiap perilaku manusia. Karena menyangkut perilaku, maka belajar juga dapat dilihat dalam perspektif bihavioristik. Menurut paham ini, pendidikan adalah untuk membentuk sikap perilaku anggota masyarakat. Oleh karena itu menurut aliran bihaviorisme, belajar adalah merubah perilaku siswa dari tidak bisa menjadi bisa, dari tidak mengerti menjadi mengerti dan berperilaku sesuai dengan nilai-nilai yang berlaku dalam masyarakat.

Disamping itu, belajar juga dapat dilihat berdasarkan aliran konstruktivisme. Menurut Kauchak (dalam Rosyada, 2007:94), aliran contructivisme menekankan tentang belajar pada empat komponen kunci yaitu: (a) Siswa membangun pemahamanya sendiri dari hasil mereka belajar bukan karena disampaikan pada mereka. (b) Pelajaran baru sangat tergantung pada pelajaran sebelumnya. (c) Belajar dapat diintegrasikan dengan interaksi sosial. (d) Penugasan-penugasan dalam belajar dapat meningkatkan kebermaknaan proses pembelajaran.

\section{Pendidikan Kewarganegaraan}

a. Hakekat Pendidikan Kewarganegaraan

Pada dasarnya pembentukan dan pengembangan karakter berdasarkan nilai-nilai pancasila dapat dilakukan melalui berbagai mata pelajaran di sekolah. Dasarnya menurut Noor Syam (1988:56), tiaptiap materi pelajaran selalu mengandung nilai-nilai baik nilai formal, nilai material maupun nilai praktis. Nilai formal adalah nilai-nilai yang membina atau membentuk kepribadian. Nilai material ialah pengetahuan atau penguasaan atas ilmu itu sendiri, baik berupa teori-teori asas-asas, maupun seluk beluk ilmu itu. Nilai praktis ialah nilai guna atau aspek praktis daripada pengetahuan yang dipelajari itu didalam kehidupan, baik bagi diri sendiri mau- pun bagi orang lain.

Salah satu mata pelajaran yang berhubungan erat sekali dengan tujuan pembentukan dan pengembangan karakter peserta didik berdasarkan nilai-nilai pancasila adalah pendidikan kewarganegaraan. Menurut Malik Fajar (dalam Zubaedi, 2011:

277-278), pendidikan kewarganegaraan memiliki peranan penting sebagai wahana untuk mengembangkan kemampuan, watak dan karakter warga negara yang bertangungjawab. Artinya pendidikan kewarganegaraan bertujuan untuk mendidik generasi muda menjadi warga negara yang nasionalis, baik, jujur, demokratis, partisipatif dan lainya.

Sebagai mata pelajaran yang tujuan utamanya pembentukan karakter warga negara maka pendidikan kewarganegaraan pada dasarnya merupakan pendidikan yang menonjolkan sisi afektif atau sikap. Oleh karena itu agar pendidikan kewarganegaraan itu efektif, ada beberapa aspek yang tidak boleh diabaikan.

Aspek tersebut seperti tujuan, materi, proses pembelajaranya dan evaluasinya harus sejalan dengan tujuan spesifik pendidikan kewarganegaraan yaitu untuk membentuk dan membangun karakter peserta didik berdasarkan nilai-nilai pancasila. Menurut Kirschenbaum (dalam Zuhcdi 2008, 40), aspek-spek utama pendidikan kewarganegaraan meliputi pengetahuan untuk menjadi warga negara yang baik, apresiasi terhadap sistem demokrasi dan nilai-nilai kewargaan, keterampilan berpikir kritis, keterampilan berkomunikasi, keterampilan bekerja sama dan keterampilan mengatasi konflik.

Mengingat tujuan utama ini maka materi pendidikan kewarganegaraan sangat beragam. Menurut Dede Rosada (2003: xii- xiii.), pendidikan kewarganengaraan yang efektif, materinya mencakup empat hal yaitu : pertama, pemahaman dasar tentang cara kerja demokrasi dan lembaga-lembaganya, kedua, pemahaman tentang rule of law dan human rights seperti tercermin dalam rumusanrumusan, perjanjian dan kesepakatan internasional dan lokal. Ketiga, penguatan keterampilan partisipatif untuk memberdayakan peserta didik dalam merespon dan memecahkan masalah-masalah masyarakat mereka secara demokratis, keempat, pengembangan budaya demokrasi dan perdamaian pada lembaga-lembaga pendidikan dan seluruh aspek kehidupan masyarakat. Selanjutnya, menurut Numan Sumantri (2001:8-11), materi pendidikan kewargaanegara secara umum seperti politik atau demokrasi, ham, negara, hukum, dan masyarakat madani. Kesemua materi tersebut merupakan materi pokok yang harus di perkenalkan dan diajarkan 
Irwan S atria| Model Pembelajaran Penanaman Nilai-Nilai Pancasila 156

serta disosialisasikan pada peserta didik.

Mengingat begitu besarnya tujuan pendidikan kewarganegaraan dalam rangka pembentukan dan pengembangan karakter peserta didik berdasarkan nilai-nilai pancasila maka pendidikan kewarganegaraan perlu dituangkan dalam bentuk standar nasional, standar materi serta model-model pembelajaran yang efektif, dengan memperhatikan empat hal yaitu : Pertama, pendidikan kewarganegaraan perlu mengembangkan kemampuan dasar terkait dengan kemampuan intelektual, sosial (berpikir, bersikap, bertindak serta berpartisipasi dalam hidup masyarakat). Kedua, pendidikan kewarganegaraan perlu mengembangkan daya nalar (state of mind) peserta didik/ pengembangan kecerdasan (civic intelegence), tanggungjawab (civic responsibility), dan partisipasi (civic participation) warga negara sebagai landasan pengembangan nilai dan perilaku. Ketiga, pendidikan kewarganegaraan perlu mengembangkan pendekatan pembelajaran yang lebih imperatif dengan menekankan pada pelatihan penggunaan logika dan penalaran. Keempat, kelas pendidikan kewarganegaraan sebagai laboratorium. Artinya kelas merupakan media untuk melakukan proses ujicoba penanaman, pembentukan dan pengembangan nilai-nilai peserta didik.

Dari penjelasan di atas dapat dikatakan bahwa pendidikan kewarganegaraan merupakan pendidikan yang mengutamakan pembentukan afektif atau sikap perilaku peserta didik. Dalam arti luas, pendidikan kewarganegaraan merupakan pendidikan untuk membentuk karakter peserta didik berdasarkan nilai-nilai pancasila.

b. P.Kwn sebagai pendidikan karakter berbasis nilai-nilai pancasila

Secara filosofis, pendidikan adalah suatu upaya yang dilakukan dalam dunia pendidikan sehingga peserta didik diharapkan berguna bagi kehidupan dalam kedudukannya sebagai pribadi, anggota masyarakat dan sekaligus warga negara suatu negara. Oleh karena itu secara substantif dan berdasarkan pada tujuan utama pendidikan kewarganegaraan maka pendidikan kewarganegaraan merupakan ekual dengan pendidikan karakter yang menyangkut sosialisasi, aktualisasi dan implementasi konsep, sistem, nilai-nilai dan praktiknya melalui pendidikan.

Lickona (1992) mendefinisikan pendidikan karakter sebagai "deliberate effort to help people understand, care about, and act upon core ethical values". Dari pandangan tersebut dapat dikatakan bahwa pendidikan karakter pada intinya adalah membantu masyarakat atau seseorang untuk dapat memahami tentang nilai-nilai etika.

Selanjutnya Lickona, menyatakan bahwa pendidikan karakter adalah pendidikan untuk membentuk kepribadian seseorang melalui pendidikan budi pekerti, yang hasilnya terlihat dalam tindakan nyata seseorang, yaitu tingkah laku yang baik, jujur, bertanggung jawab, menghormati orang lain, kerja keras, dan sebagainya. Russel William (dalam Q-Aness dan Hambali, 2008:99) mengilustrasikan pendidikan karakter ibarat otot, dimana otot-otot karakter akan menjadi lembek apabila tidak pernah dilatih, dan akan kuat serta kokoh kalau sering dipakai. Ini berarti, hakikat dasar pendidikan karakter adalah apa yang menjadi potensi manusia harus dikembangkan. Pada diri manusia terdapat bibit potensi kebenaran dan kebaikan yang harus didorong melalui pendidikan aktual.

Menurut Zaim, (2008: 103), membangun karakter adalah proses mengukir atau memahat jiwa sedemikian rupa sehingga berbentuk unik, menarik dan berbeda atau dapat dibedakan dengan orang lain. Peserta didik dilatih untuk mengembangkan karakter baik dalam berbagai kegiatan sekolah maupun melalui proses pembelajaran. Didalam proses pembelajaran, sejumlah nilai dimasukan kedalam jiwa peserta didik sehingga mewarnai jiwa peserta didik dan nampak dalam perilaku sehari-hari.

Menurut Forester (dalam Zaim Elmubarok (2008:104), ada empat ciri dasar dalam pendidikan karakter yaitu: (1) keteraturan interior diantara setiap tindakan diukur berdasarkan nilai. Nilai menjadi pedoman normatif setiap tindakan. (2) Koherensi yang memberi keberanian, membuat seseorang teguh pada prinsip, tidak terombang ambing pada situasi atau takut resiko. Koherensi merupakan dasar membangun rasa percaya satu sama lain. Tidak adanya koherensi meruntuhkan kredibilitas seseorang. (3) Otonomi yaitu menginternalisasikan aturan dari luar sampai menjadi nilai-nilai bagi pribadi. (4) Keteguhan dan kesetiaan. Keteguhan merupakan daya tahan seseorang guna mengingini apa yang dipandang baik dan kesetiaan merupakan dasar bagi penghormatan atas komitmen yang dipilih .

Menurut Djaali, anak yang mula-mula kurang terlatih dan membentuk proyeksi terhadap dirinya sebagai individu yang tadinya kurang terkontrol dalam memasuki alam manusia yang berfungsi aktif, akhirnya akan menjadi lebih terkontrol dalam hal: 1) penggunaan kata-kata yang lebih ramah dan bersahabat, 2) tingkah laku sosialnya akan lebih dapat dikendalikan sesuai aturan yang berlaku, 3) 
Irwan S atria| Model Pembelajaran Penanaman Nilai-Nilai Pancasila 157

adanya penghargaan terhadap orang lain dan, 4) tanggung jawab sebagai anggota dari suatu kelompok dan masyarakat.

Pendidikan karakter mengembangkan semua potensi anak sehingga menjadi manusia seutuhnya. Dengan arti, pendidikan karakter sangat penting untuk perkembangan peserta didik secara holistik karena perkembangan anak harus seimbang, baik dari segi akademik maupun segi sosial dan emosi.

Menurut Mansyur Ramly (2010:8), tujuan pendidikan karakter adalah, mengembangkan potensi kalbu/nurani/afektif peserta didik sebagai manusia dan warganegara yang memiliki nilai-nilai budaya dan karakter bangsa, mengembangkan kebiasaan dan perilaku peserta didik yang terpuji dan sejalan dengan nilai-nilai universal dan tradisi budaya bangsa yang religius, menanamkan jiwa kepemimpinan dan tanggung jawab peserta didik sebagai generasi penerus bangsa, mengembangkan kemampuan peserta didik menjadi manusia yang mandiri, kreatif, berwawasan kebangsaan dan mengembangkan lingkungan kehidupan sekolah sebagai lingkungan belajar yang aman, jujur, penuh kreativitas dan persahabatan, serta dengan rasa kebangsaan yang tinggi dan penuh kekuatan (dignity).

Dengan demikian pendidikan karakter bertujuan untuk pengembangan kehidupan manusia baik pengembangan pengetahuan, mental maupun spiritual melalu proses pembelajaran berdasarkan nilai-nilai sosial budaya sehingga menjadi manusia yang bertaqwa, cerdas, mandiri, dan menghargai nilai-nilai kemanusiaan. Hakekatnya, muara dari pendidikan terletak pada hasil proses pembelajaran yaitu dengan terbentuknya kepribadian atau karakter peserta didik berdasarkan nilai-nilai karakter.

Untuk itu di dalam pendidikan karakter ada beberapa prinsip yang sangat penting. Menurut Mansyur Ramly (2010:11), pertama, manusia adalah makhluk yang dipengaruhi dua aspek, pada dirinya memiliki sumber kebenaran dan dari luar dirinya ada juga dorongan atau kondisi yang mempengaruhi kesadarannya. Atas dasar prinsip ini, pendidikan karakter tidaklah bersifat teoritis (meyakini telah ada konsep yang akan dijadikan rujukan karakter), tetapi melibatkan penciptaan situasi yang mengondisikan peserta didik mencapai pemenuhan karakter utamanya. Penciptaan konteks (komunitas belajar),terutama pembelajaran yang baik, dan pemahaman akan konteks peserta didik (latar belakang dan perkembangan psikologi) menjadi bagian dari pendidikan karakter.

Kedua, menganggap bahwa perilaku yang dibimbing oleh nilai-nilai utama sebagai bukti dari karakter. Pendidikan karakter tidak meyakini adanya pemisahan antara roh, jiwa dan badan. Karakter dibangun oleh peran roh, juga badan, yaitu melalui perkataan, keyakinan, dan tindakan. Tanpa tindakan, semua yang diucapkan dan diyakini bukanlah apa-apa. Tanpa kenyataan sesuai perkataan, tindakan dan keyakinan tidak akan terhubung.

Ketiga, pendidikan karakter mengutamakan munculnya kesadaran pribadi peserta didik untuk secara ikhlas mengutamakan pembangunan karakter positif. Setiap manusia memiliki modal dasar sebagai potensi dan kapasitasnya yang khas, yang membedakan dirinya dengan orang lain. Aktualisasi dari kesadaran ini dalam dunia pendidikan adalah pemupukan karakter posisitf seperti keandalan khusus seseorang yang memungkinkannya memiliki daya tahan dan daya saing dalam perjuangan hidup.

Keempat, pendidikan karakter mengarahkan peserta didik untuk menjadi manusia ulul albab yang tidak hanya memiliki kesadaran diri, tetapi juga kesadaran untuk terus mengembangkan diri, sesuai dengan pengetahuan dan karakter yang dimilikinya. Manusia ulul albab adalah manusia yang dapat diandalkan untuk semua aspek, baik aspek intelektual, afektif, maupun spiritual.

Kelima, karakter seseorang ditentukan oleh apa yang dilakukannya berdasarkan pilihan. Setiap keputusan yang diambil menentukan akan kualitas seseorang di mata orang lain. Seorang individu dengan karakter yang baik bisa mengubah dunia secara perlahan-lahan. Berdasarkan penjelasan di atas maka pendidikan karakter intinya adalah pendidikan nilai.

Dengan demikian, pendidikan kewarganegaraan erat kaitannya dengan habit atau kebiasaan yang terus menerus dipraktekkan dan dilakukan. Hal ini sejalan dengan pandangan bahwa pendidikan karakter yang baik, harus melibatkan bukan saja aspek pengetahuan yang baik (moral knowing), tetapi juga merasakan dengan baik atau loving the good (moral feeling), dan perilaku yang baik (moral action) berdasarkan nilai-nilai pancasila.

\section{c. Nilai dan Nilai-Nilai Pancasila}

Nilai adalah sesuatu yang dijadikan pedoman dalam berperilaku. Nilai pada umumnya bersifat universal artinya berlaku dan diakui oleh anggota masyarakat. Seluruh agama, tradisi, dan budaya menjunjung tinggi nilai. Nilai universal menjadi perekat bagi seluruh anggota masyarakat walaupun berbeda latar belakang budaya, suku, dan agama.

Nilai sangat banyak, tergantung dari keyakinan, 
Irwan S atria| Model Pembelajaran Penanaman Nilai-Nilai Pancasila 158

tradisi atau budaya suatu masyarakat. Oleh karena itu identifikasi nilai-nilai merupakan hal yang mutlak. Tanpa identifikasi nilai maka pendidikan kewarganegaraan hanya akan menjadi sebuah usaha hampa, perjalanan tanpa ujung, petualangan tanpa peta dan berakhir sia-sia. Yang perlu diingat adalah ketika mengidentifikasi nilai-nilai, selalu terkait dengan sumber-sumber nilai.

Sebagai sumber nilai-nilai di Indonesia adalah dari nilai-nilai sosial budaya Indonesia. Menurut Mansyur Ramly (2010:9-10), nilai-nilai yang dikembangkan berasal dari identifikasi sumber-sumber :

1. Agama: masyarakat Indonesia adalah masyarakat beragama. Oleh karena itu, kehidupan individu, masyarakat, dan bangsa selalu didasari pada ajaran agama dan kepercayaannya. Secara politis, kehidupan kenegaraan pun didasari pada nilai-nilai yang berasal dari agama. Atas dasar pertimbangan itu, nilai-nilai pendidikan karakter harus didasarkan pada nilainilai dan kaidah yang berasal dari agama.

2. Budaya: sebagai suatu kebenaran bahwa tidak ada manusia yang hidup bermasyarakat yang tidak didasari oleh nilai-nilai budaya yang diakui masyarakat itu. Nilai-nilai budaya itu dijadikan dasar dalam pemberian makna terhadap suatu konsep dan arti dalam komunikasi antaranggota masyarakat itu. Posisi budaya yang demikian penting dalam kehidupan masyarakat mengharuskan budaya menjadi sumber nilai dalam pendidikan karakter.

3. Tujuan Pendidikan Nasional: Tujuan pendidikan nasional memuat berbagai nilai kemanusiaan yang harus dimiliki warga negara Indonesia. Oleh karena itu, tujuan pendidikan nasional adalah sumber yang paling operasional dalam pengembangan pendidikan karakter. Pendidikan karakter dikembangkan oleh berbagai satuan pendidikan di berbagai jenjang dan jalur.

Pada dasarnya, nilai-nilai sebagai dasar pembentukan karakter selaras dengan 5 pilar karakteristik manusia :

1. Transendensi: Menyadari bahwa manusia merupakan ciptaan Tuhan yang maha Esa. Darinya akan memunculkan penghambaan semata-mata pada Tuhannya yang Esa. Kesadaran ini juga berarti memahami keberadaan diri dan alam sekitar sehingga mampu memakmurkannya.

2. Humanisasi: Setiap manusia pada hakekatnya setara di mata Tuhan kecuali ilmu dan ketakwaan yang membedakannya. Manusia diciptakan sebagai subjek yang memiliki potensi.

3. Kebinekaan: Kesadaran akan ada sekian ban- yak perbedaan di dunia. Akan tetapi, mampu mengambil kesamaan untuk menumbuhkan kekuatan.

4. Liberasi: Pembebasan atas penindasan sesama manusia. Oleh sebab itu tidak dibenarkan adanya penjajahan manusia oleh manusia.

5. Keadilan: Keadilan merupakan kunci kesejahteraan. Adil tidak berarti sama, tetapi proporsional.

Sehubungan dengan nilai, Thomas Lickona mengemukakan beberapa nilai dalam pendidikan karakter yang disosialisasikan dalam pendidikan yaitu

kepercayaan, respek, tanggungjawab, keadilan, perawatan, kejujuran, keberanian, ketekunan, integritas dan kewarganegaraan. Kemendiknas juga mengidentifikasi 18 nilai dalam pendidikan karakter : yaitu :

1. Religius. Sikap dan perilaku yang patuh dalam melaksanakan ajaran agama yang dianutnya, toleran terhadap pelaksanaan ibadah agama lain, dan hidup rukun dengan pemeluk agama lain.

2. Jujur. Perilaku yang didasarkan pada upaya menjadikan dirinya sebagai orang yang selalu dapat dipercaya dalam perkataan, tindakan, dan pekerjaan.

3. Toleransi. Sikap dan tindakan yang menghargai perbedaan agama, suku, etnis, pendapat, sikap, dan tindakan orang lain yang berbeda dari dirinya.

4. Disiplin. Tindakan yang menunjukkan perilaku tertib dan patuh pada berbagai ketentuan dan peraturan.

5. Kerja Keras. Tindakan yang menunjukkan perilaku tertib dan patuh pada berbagai ketentuan dan peraturan.

6 Kreatif. Berpikir dan melakukan sesuatu untuk menghasilkan cara atau hasil baru dari sesuatu yang telah dimiliki.

7 Mandiri.Sikap dan perilaku yang tidak mudah tergantung pada orang lain dalam menyelesaikan tugas-tugas.

8 Demokratis. Cara berfikir, bersikap, dan bertindak yang menilai sama hak dan kewajiban dirinya dan orang lain.

9 Rasa Ingin Tahu. Sikap dan tindakan yang selalu berupaya untuk mengetahui lebih mendalam dan meluas dari sesuatu yang dipelajarinya, dilihat, dan didengar.

10. Semangat Kebangsaan. Cara berpikir, bertindak, dan berwawasan yang menempatkan kepentingan bangsa dan negara di atas kepentin- 
Irwan S atria| Model Pembelajaran Penanaman Nilai-Nilai Pancasila 159

gan diri dan kelompoknya.

11. Cinta Tanah Air. Cara berpikir, bertindak, dan berwawasan yang menempatkan kepentingan bangsa dan negara di atas kepentingan diri dan kelompoknya.

12. Menghargai Prestasi. Sikap dan tindakan yang mendorong dirinya untuk menghasilkan sesuatu yang berguna bagi masyarakat, dan mengakui, serta menghormati keberhasilan orang lain.

13. Bersahabat/Komunikatif. Sikap dan tindakan yang mendorong dirinya untuk menghasilkan sesuatu yang berguna bagi masyarakat, dan mengakui, serta menghormati keberhasilan orang lain.

14.Cinta Damai. Sikap dan tindakan yang mendorong dirinya untuk menghasilkan sesuatu yang berguna bagi masyarakat, dan mengakui, serta menghormati keberhasilan orang lain.

15.Gemar Membaca. Kebiasaan menyediakan waktu untuk membaca berbagai bacaan yang memberikan kebajikan bagi dirinya.

16. Peduli Lingkungan. Sikap dan tindakan yang selalu berupaya mencegah kerusakan pada lingkungan alam di sekitarnya, dan mengembangkan upaya-upaya untuk memperbaiki kerusakan alam yang sudah terjadi.

17. Peduli Sosial. Sikap dan tindakan yang selalu ingin memberi bantuan pada orang lain dan masyarakat yang membutuhkan.

18. Tanggungjawab. Sikap dan perilaku seseorang untuk melaksanakan tugas dan kewajibannya, yang seharusnya dia lakukan, terhadap diri sendiri, masyarakat, lingkungan (alam, sosial dan budaya), negara dan Tuhan Yang Maha Esa.

Megawangi (2001) juga merumuskan sembilan nilai dasar yang akan menjadi karakter dasar dalam pendidikan yaitu : Cinta kepada Tuhan dan segenap ciptaannya (love Allah, trust, reverence, loyalty), kemandirian dan tanggung jawab (responsibility, excellence, self reliance, discipline, orderness), Kejujuran/amanah, bijaksana (trustworthiness, reliability, honesy), Hormat dan santun (respect, courtesy, obedience), Dermawan, suka menolong dan gotong royong (love, compassion, caring, emphaty, generousity, moderation, cooperation), Percaya diri, kreatif dan pekerja keras (confidience, assertiveness, creativity, resourcefutness, courage, determination and enthusiasm), Kepemimpinan dan keadilan (kindness, friendliness, humility, modesty), Baik dan rendah hati (tolerance, flexibility, peacefulness, unity).

\section{Nilai-nilai Pancasila}

Inti dari nilai dalam kehidupan berbangsa dan bernegara di Indonesia adalah pancasila. Pancasila merupakan nilai dasar yang menjadi pedoman dalam kehidupan berbangsa dan bernegara. Di dalam pendidikan kewarganegaraan, nilai yang ditonjolkan adalah nilai-nilai pancasila. Dasar pertimbangannya adalah pendidikan berdasarkan nilai-nilai pancasila sangat berfungsi dalam membentuk karakter bangsa. Melalui pendidikan kewarganegaraan berbasis nilai-nilai pancasila menjadikan warga negara berkarakter pancasila.

Menurut Notonagoro (1983:26-28), pancasila merupakan inti dari nilai-nilai kehidupan sosial masyarakat yang berasal dari kebudayaan, kebiasaan dan agama-agama bangsa Indonesia. Hal yang sama juga diungkapkan oleh Adnan (2003:146) dan Kaelan (1999:65-67), bahwa pancasila mempunyai nilai-nilai dasar yaitu nilai ketuhanan, kemanusiaan, persatuan, demokrasi, dan keadilan.

Lebih jauh menurut Kaelan (1999:65), di dalam pancasila terdapat beberapa nilai dasar yaitu nilai-nilai yang mendasari kehidupan manusia, nilai instrumental yang merupakan arahan, kebijakan, strategi, sasaran serta lembaga pelaksananya dan nilai praksis yaitu realisasi nilai-nilai instrumental dalam suatu relasiasi pengamalan nyata dalam kehidupan sehari-hari dalam masyarakat, bangsa dan negara. Lima (5) nilai dasar inilah yang menjadi dasar pembentukan karakter peserta didik.

Didalam pelaksanaan, 5 nilai dasar dijadikan sebagai pedoman dalam bersikap dan berperilaku yang ditetapkan dalam Tap MPR No II tahu 1978 terdiri dari :

1. Sila ketuhanan :

a. Percaya dan taqwa kepada Tuhan YME sesuai dengan agama dan kepercayaan masing-masing menurut dasar kemanusiaan yang adil dan beradab.

b. Hormat menghormati dan bekerja sama antar pemeluk agama dan penganut-penganut kepercayaan yang berbeda-beda, sehingga terbina kerukunan hidup.

c. Saling menghormati kebebasan menjalankan ibadah sesuai dengan agama dan kepercayaan.

d. Tidak memaksakan agama dan kepercayaan kepada orang lain.

2. Sila kemanusiaan yang adil dan beradab :

a. Mengakui persamaan derajat, persamaan hak, dan persamaan kewajiban antar sesama manusia.

b. Saling mencintai sesama manusia. 
Irwan S atria| Model Pembelajaran Penanaman Nilai-Nilai Pancasila 160

c. Mengembangkan sikap tenggang rasa.

d. Tidak semena-mena terhadap orang lain.

e. Menjunjung tinggi nilai kemanusiaan.

f. Gemar melakukan melakukan kegiatan kemanusiaan.

g. Berani membela kebenaran dan keadilan.

3. Sila Persatuan Indonesia.

a. Menempatkan persatuan, kesatuan, kepentingan dan keselamatan bangsa dan negara di atas kepentingan pribadi dan golongan.

b. Rela berkorban untuk kepentingan bangsa dan negara.

c. Cinta tanah air dan bangsa.

d. Bangga sebagai bangsa Indonesia dan bertanah air Indonesia.

e. Memajukan pergaulan demi persatuan dan kesatuan bangsa yang berbhinneka tunggal ika.

4. Sila kerakyatan yang dipimpin oleh hikmat kebijaksanaan dalam permusyawaratan/perwakilan :

a. Mengutamakan kepentingan negara dan masyarakat.

b. Tidak memaksakan kehendak pada orang lain.

c. Mengutamakan musyawarah dalam mengambil keputusan untuk kepentingan bersama.

d. Musyawarah untuk mencapai mufakat diliputi oleh semangat kekeluargaan.

e. Dengan itikat baik dan rasa tangung jawab menerima dan melaksanakan hasil keputusan musyawarah.

f. Musyawarah dilakukan dengan akal sehat dan sesuai dengan hati nurani yang luhur.

g. Keputusan yang diambil harus dapat dipertanggungjawabkan secara moral kepada tuhan YME, menjunjung tinggi harkat dan martabat manusia serta nilai-nilai kebenaran dan keadilan.

5. Sila keadilan bagi seluruh rakyat Indonesia.

a. Mengembangkan perbuatan-perbuatan yang luhur yang mencerminkan sikap dan suasana kekeluargaan dan kegotongroyongan.

b. Bersikap adil.

c. Menjaga keseimbangan antara hak dan kewajiban.

d. Menghormati hak-hak orang lain.

e. Suka memberi pertolongan kepada orang lain.

f. Menjauhi sikap pemerasan pada orang lain.

g. Tidak bersifat boros.

h. Tidak bergaya hidup mewah. i. Tidak melakukan perbuatan yang merugikan kepentingan umum.

j. Suka bekerja keras.

k. Menghargai hasil karya orang lain.

1. Bersama-sama berusaha mewujudkan kemajuan yang merata dan berkeadilan sosial.

\section{Pembelajaran Kontekstual}

a. Pengertian dan Hekakat Pembelajaran Kontekstual

Salah satu dari model pembelajaran adalah pembelajaran kontekstual atau contextual learning (CTL). Menurut Rusman (2011:187), pembelajaran kontekstual adalah sistem yang merangsang otak untuk menyusun pola-pola yang mewujudkan makna. Menurut E. B. Johnson (2006), pembelajaran kontekstual merupakan usaha untuk membuat siswa aktif dalam memompa kemampuan diri tanpa merugi dari segi manfaat, sebab siswa berusaha mempelajari konsep sekaligus menerapkan dan mengaitkannya dengan dunia nyata.

Hal ini menyebabkan pembelajaran kontekstual berbeda dengan pembelajaran konvensional. Pembelajaran konvensional hanya berfokus pada materi yang bisa untuk dihafal. Konsep pembelajaran ini, hanya memfokuskan pada pemberian pembekalan kemampuan pengetahuan yang bersifat teoritis. Konsep ini dikenal dengan datang, duduk, dengar, catat dan hafal (DDDCH). Padahal, pembelajaran merupakan suatu aktivitas yang komplek dimana melibatkan keseluruhan aspek yaitu kognitif, afektif dan psikomotorik peserta didik.

Pada pembelajaran kontekstual, memungkinkan peserta didik aktif, berkembang sesuai dengan potensinya. Didalam proses pembelajaran, yang utama adalah perlu mengaitkan seluruh aspek tersebut. Untuk mengaitkannya bisa dilakukan dengan berbagai cara, misalnya materi yang dipelajari secara langsung terkait dengan kondisi faktual yang terkait dengan pengalaman hidup yang nyata. Menurut Rusman (2011:187), inti dari pendekatan CTL adalah keterkaitan materi atau topik dengan kehidupan nyata. Jadi di dalam pembelajaran kontekstual adalah bagaimana agar pengalaman belajar yang dimiliki siswa senantiasa terkait dengan permasalahan-permasalahan aktual yang terjadi di lingkungannya.

Menurut Nurhadi dalam Rusman (2011:189), pembelajaran kontekstual (contextual taching and learning atau CTL) merupakan konsep belajar yang dapat membantu guru mengaitkan antara materi yang diajarkannya dengan situasi dunia nyata siswa dan mendorong siswa membuat hubungan antara 
Irwan S atria| Model Pembelajaran Penanaman Nilai-Nilai Pancasila 161

pengetahuan yang dimilikinya dengan penerapannya dalam kehidupan mereka sebagai anggota keluarga dan masyarakat. Selanjutnya menurut Rusman (2011: 189), melalui pembelajaran kontekstual, mengajar bukan transformasi pengetahuan dari guru kepada siswa dengan menghafal sejumlah konsep-konsep yang sepertinya terlepas dari kehidupan, akan tetapi lebih ditekankan pada upaya memfasilitasi siswa untuk mencapai kemampuan untuk bisa hidup (life skill) dari apa yang dipelajarinya.

Menurut Howey R, Keneth dalam (Rusman 2011), CTL adalah pembelajaran yang memungkinkan terjadinya proses belajar pengalaman siswa menggunakan pemahaman dan kemampuan akademiknya dalam berbagai konteks dalam dan luar sekolah untuk memecahkan masalah yang bersifat simulative ataupun nyata, baik sendiri-sendiri maupun bersama-sama. Dengan demikian pembelajaran kontekstual memberi kesempatan kepada peserta didik berpartisipasi secara luas dalam pembelajaran.

b. Langkah-langkah pembelajaran kontekstual

Pembelajaran CTL mempunyai ciri yang berbeda dengan pendekatan lainnya. Menurut Johnson (2006), ciri khas CTL ditandai oleh tujuh komponen utama, yaitu: (1) constructivism, (2) inquiry, (3) questioning, (4) learning community, (5) modeling, (6) reflection dan, (7) authentic assessment.

Selanjutnya menurut Rusman (2011:191), Pengembangan setiap komponen CTL dalam pembelajaran dapat dilakukan melalui langkah-langkah sebagai berikut:

1) Mengembangkan pemikiran siswa untuk melakukan kegiatan belajar lebih bermakna, apakah dengan bekerja sendiri, menemukan sendiri dan mengkonstruksi sendiri pengetahuan dan keterampilan baru yang akan dimilikinya. Artinya siswa mengetahui arti makna yang dipelajarinya.

2) Melaksanakan sejauh mungkin kegiatan inquiry untuk semua topik yang diajarkan.

3) Mengembangkan sifat ingin tahu siswa melalui memunculkan pertanyaan-pertanyaan atau kegiatan lain.

4) Menciptakan masyarakat belajar, seperti melalui kegiatan kelompok berdiskusi, tanya jawab dan lain sebagainya.

5) Menghadirkan model sebagai contoh pembelajaran, bisa melalui ilustrasi, model bahkan media yang sebenarnya.

6) Membiasakan anak untuk melakukan refleksi dari setiap kegiatan pembelajaran yang telah dilakukan.

7) Melakukan penilaian secara objektif, yaitu melalui kemampuan yang sebenarnya pada setiap siswa.

c. Prinsip-prinsip pembelajaran kontekstual

Model pembelajaran kontekstual mempunyai prinsip-prinsip. Menurut Elaine B, Johnson (2006:68-72), tiga prinsip utama ilmiah dalam CTL yaitu: pertama, prinsip kesaling-bergantungan. Pada prinsip ini siswa diajak memahami bahwa dalam kehidupan terdapat saling bergantung antara yang satu dengan yang lainnya. Prinsip saling bergantungan ada dalam segala kehidupan sehingga memungkinkan siswa untuk membuat hubungan yang bermakna. Prinsip ini membawa pada beberapa efek yaitu : mendukung kerjasama dan mendengarkan.

Selanjutnya menurut Elaine B. Johnson (2006:74), dalam proses pembelajaran, kesaling bergantungan memerlukan penghubungan, penggabungan, berpikir kritis dan kreatif, merumuskan tujuan yang jelas, menetapkan standar yang tinggi melakukan tugas-tugas yang berarti untuk semua, menghargai setiap orang dan menggunakan metode penilaian yang menghubungkan pembelajaran dengan dunia nyata. Jadi praktik kesaling bergantungan menumbuhkan hubungan yang bermakna.

Kedua,prinsipdiferensiensi. MenurutB.Johnson (2006:79), prinsip diferensiensi juga mengajak kerjasama sehingga memungkinkan dua entitas yang berbeda untuk bersatu dan bekerja sama dalam pencarian makna berupa nilai-nilai kebangsaan. Diferensiensi merupakan suatu anugerah tuhan yang tak ternilai. Tuhan yang menciptakan alam tidak pernah membuat hal yang sama. Oleh karena itu keberagaman merupakan sesuatu yang given adanya. Dalam konsep ini, proses pembelajaran yang menantang bagi siswa untuk terus menerus aktif. Para siswa diajak berpikir kreatif berdasarkan pengetahuan akademiknya dalam rangka untuk mencari sebuah makna dari apa yang dipelajarinya. Mungkin saja ada perbedaan makna yang di peroleh oleh siswa akan tetapi itulah diferensiasi yang unik.

Ketiga, Prinsip pengaturan diri. Pada prinsip ini meminta para pendidik untuk mendorong siswa untuk mengeluarkan seluruh potensinya. Sasaran utama CTL adalah mendorong siswa untuk mencapai keunggulan akademik, memperoleh keterampilan karier, dan mengembangkan karakter dengan cara menghubungkan tugas sekolah dengan pengalaman serta pengetahuan pribadinya. Ketika proses ini berlangsung mereka terlibat dalam proses pen- 
Irwan S atria| Model Pembelajaran Penanaman Nilai-Nilai Pancasila 162

gaturan diri. CTL membantu para siswa menemukan makna dalam pelajaran mereka dengan cara menghubungkan materi akademik dengan konteks kehidupan keseharian mereka. Mereka membuat hubungan-hubungan penting yang menghasilkan makna dengan melaksanakan pembelajaran yang diatur sendiri, bekerja sama, berpikir kritis dan kreatif, menghargai orang lain, mencapai standar yang tinggi dan berperan serta dalam tugas-tugas penilaian otentik.

Dengan demikian, pendekatan pembelajaran kontekstual pada mata pelajaran pendidikan kewargaanegara khususnya berdasarkan nilai-nilai pancasila menjadikan proses pembelajaran lebih bermakna, karena pembelajaran lebih dekat dengan lingkungan masyarakat (bukan dekat dari segi fisik), akan tetapi secara fungsional apa yang dipelajari senantiasa bersentuhan dengan situasi dan permasalahan kehidupan yang terjadi di lingkungan keluarga, masyarakat bangsa dan negara.

Berdasarkan penjelasan di atas dan untuk mencapai tujuan tersebut, perlu penanaman nilai-nilai pancasila dalam pembelajaran pendidikan kewarganegaraan melalui pendekatan CTL. Di dalam pendekatan CTL, peserta didik diajak untuk mencari makna dari fakta-fakta yang terjadi dalam kehidupan sehari-hari. Pendidik memberi stimulus dengan berbagai kasus atau fakta-fakta sosial yang terjadi di masyarakat dan siswa akan memberikan respon. Dari hasil respon tergambar sikap peserta didik. Dengan stimulus respon yang berulangulang, nilai-nilai pancasila akan tertanam dalam diri peserta didik.

\section{Pendekatan Contextual teaching and learning da- lam Penanaman nilai-nilai Pancasila}

Berdasarkan Renstra pendidikan karakter yang dikeluarkan Kementerian Pendidikan dan Kebudayaan, secara umum ada tahapan pendekatan yaitu pengenalan nilai dan pembiasaan perilaku sesuai dengan nilai-nilai. Tahapan pertama adalah berkenaan dengan moral knowing, moral loving dan moral doing (acting). Moral knowing berkenaan dengan kesadaran (awareness), nilai-nilai (values), sudut pandang (perspective taking), logika (reasoning), menentukan sikap (decision making), dan pengenalan diri (self knowledge). Kedua adalah Moral loving berkenaan dengan kepercayaan diri (self esteem), kepekaan terhadap orang lain (emphaty), mencintai kebenaran (loving the good), pengendalian diri (self control), dan kerendahan hati (humility). Dan ketiga adalah Moral doing berkenaan dengan perwujudan dari moral knowing dan moral loving yang berbentuk tabiat reflektif dalam perilaku keseharian.

Secara terperinci tahapan-tahapan pendidikan karakter dalam diri setiap peserta didik yaitu :

1) Moral Knowing.

Tahapan ini merupakan langkah pertama dalam pendidikan berdasarkan nilai-nilai pancasila. Dalam tahapan ini tujuan pembelajaran adalah:

- Peserta didik mampu mengklasifikasi nilai-nilai pancasila.

- Peserta didik memahami secara logis dan rasional (bukan secara dogmatis dan doktriner) pentingnya nilai-nila pancasila.

- Pesertadidik mengenal sosok pahlawan bangsa sebagai figur teladan dalam kehidupannya.

Dalam tahap Moral Knowing, guru mengajukan pertanyaan tentang arti nilai pancasila? perilaku bertentangan dengan nilai-nilai pancasila ?. Peserta didik diminta mendiskusikan dalam kelompok kecil tentang bentuk-bentuk nyata dari perkataan, perbuatan yang baik sesuai dengan nilai pancasila, manfaat yang diperoleh dan dampak negatifnya. Dalam tahapan ini akal pemikiran anak diajak berfikir tentang pentingnya berperilaku sesuai nilainilai pancasila.

2) Moral Loving

Tahapan ini dimaksudkan untuk menumbuhkan rasa cinta dan rasa butuh terhadap nilai-nilai pancasila. Dalam tahapan ini yang menjadi sasaran adalah dimensi emosional peserta didik, hati, atau jiwa, bukan lagi akal, rasio dan logika. Guru menyentuh emosi peserta didik sehingga tumbuh kesadaran, keingintahuan. Untuk mencapai tahapan ini bisa memulai atau memasukinya dengan kisahkisah yang menyentuh hati, modeling, atau kontempelasi. Melalui tahap ini, peserta didik diharapkan mampu menilai dirinya sendiri.

Dalam tahap Moral Loving, untuk menyentuh sisi emosional peserta didik guru dapat melakukan alternatif berikut :

1. Menyampaikan kisah yang menarik dan menyentuh yang berkaitan dengan perjuangan para pahlawan

2. Bermain peran atau sosiodrama. Peserta didik dibawa pada situasi bagaimana perasaannya. Dengan cara ini diharapkan peserta didik sendiri yang menyimpulkan pentingnya menjaga nilai-nilai panasila.

3. Kontempelasi atau perenungan dengan mengajak peserta didik merenungkan tentang perilaku yang telah dilakukan sesuai dengan nilainilai pancasila.

4. Sharing pengalaman sesama peserta didik ten- 
tang nilai-nilai pancasila.

3) Moral Doing.

Moral Doing merupakan tahapan puncak proses pendidikan. Peserta didik mempraktekkan nilainilai pancasila itu dalam perilakunya sehari-hari. Peserta didik sopan, menaati aturan ramah, penyayang, jujur, disiplin, dan seterusnya. Dalam tahap Moral Doing, sebagai target puncak, guru perlu melakukan pengamatan terhadap perubahan perilaku peserta didik. Untuk ini, guru perlu menyiapkan format pengamatan termasuk meminta laporan dari sesama/guru atau dari peserta didik yang lain. Hal ini menjadi lebih baik bila peserta didik diberi tugas rumah (PR) mempraktekkan nilai-nilai pancasila yang telah dipelajari dengan cara setiap peserta didik memiliki buku catatan harian yang berisi pengalaman mereka dalam upaya menerapkan nilai tersebut apa adanya.

Pembelajaran yang berkenaan dengan moral knowing akan lebih banyak belajar melalui sumber belajar dan nara sumber. Pembelajaran yang berkenaan dengan moral loving akan terjadi pola saling membelajarkan secara seimbang di antara siswa. Sedangkan pembelajaran yang berkenaan dengan moral doing akan lebih banyak menggunakan pendekatan individual melalui pendampingan pemanfaatan potensi dan peluang yang sesuai dengan kondisi lingkungan siswa. Ketiga pola pembelajaran tersebut dirancang dengan sistematis agar para siswa dan guru/tutor/pendamping dapat memanfaatkan segenap nilai-nilai dan moral yang sesuai dengan potensi dan peluang yang tersedia di lingkungannya.

Dalam pendidikan berdasarkan nilai-nilai pancasila perlu penekanan-penekanan tertentu. Menurut Qomari Anwar (2010), yang mendapat penekanan lebih dalam adalah Knowing the good. Untuk membentuk karakter, anak tidak hanya sekedar tahu mengenai hal-hal yang baik, namun mereka harus dapat memahami kenapa perlu melakukan hal tersebut. Selanjutnya Sinurat (dalam Slamet Soewandi 109-110), penekanan dan pendekatan dalam pendidikan yang berhubungan dengan nilainilai pancasila sebagai berikut :

a. Memoralisasi (moralizing). Pendidik secara langsung mengajarkan sejumlah nilai yang harus menjadi pegangan hidup peserta didik. Pendekatan ini merupakan indoktrinasi dalam bentuk pemberian nasehat, kotbah, pidato, ceramah, dsb.

b. Bersikap membiarkan (a laissez-fair attitude), yaitu membiarkan peserta didik menentukan diri sendiri apa yang dimauinya, anak dibiarkan tumbuh dan berkembang secara alamiah dengan jatuh bangun dari penalarannya sendiri.

c. Menjadi model. Pendidik berusaha menampilkan diri sebagai model hidup menurut nilainilai tertentu

d. Pendekatan klarifikasi nilai. Peserta didik dilatih untuk menemukan dan mengembangkan sendiri nilai-nilai hidup yang ingin diperjuankgkan untuk menjadi dasar hidupnya.

Sehubungan dengan ini maka pendekatan yang paling memungkinkan adalah klarifikasi nilai karena peserta didik secara langsung merumuskan sendiri tentang arti nilai dan merasakan manfaatnya dalam kehidupan.

\section{Kesimpulan}

Dengan demikian pembelajaran dalam pendidikan kewargaanegara berdasarkan nilai-nilai pancasila melalui pembelajaran kontekstual menekankan pada pengenalan, mencintai dan penerapan nilai-nilai pancasila terhadap peserta didik. Peserta didik digiring pada adaptasi terhadap nilainilai pancasila sehingga menjadi manusia profetik, manusia yang berguna baik untuk kehidupan diri sendiri maupun masyarakat, bangsa dan negara. 
Irwan S atria| Model Pembelajaran Penanaman Nilai-Nilai Pancasila 164 